\title{
DECONSTRUYENDO EL DISCURSO PUNITIVO CONTEMPORÁNEO: INTRODUCCIÓN A UN PENSAMIENTO CRIMINOLÓGICO DEFERENTE Y HOSPITALARIO
}

\section{DECONSTRUCTING THE CONTEMPORARY PUNITIVE SPEECH: INTRODUCTION TO A DEFERENT CRIMINOLOGICAL AND HOSPITAL THOUGHT}

\author{
Augusto Renzo Espinoza Bonifaz \\ Universidad de San Martín de Porres \\ Orcid: 0000-0002-3641-4868 \\ https://doi.org/10.24265/voxjuris.2021.v39n2.12 \\ aespinozab@usmp.pe \\ Perú
}

\section{SUMARIO}

- ¿Qué es la deconstrucción?

- Revisando algunos conceptos significativos.

- El discurso punitivo y sus elementos.

- Deconstruyendo el discurso punitivo contemporáneo.

- De la diferencia a la deferencia.

- De la hostilidad a la hospitalidad.

- De la “imaginación” penal a la imaginación criminológica.

- Conclusiones.

- Fuentes de información.

\section{RESUMEN}

El objetivo del presente trabajo de investigación es introducir una manera diferente de pensar el discurso punitivo contemporáneo, para ello utilizaremos a la deconstrucción como estrategia para analizarlo, develarlo y redefinirlo. Lo que proponemos es reflexionar sobre algunas palabras, ideas y conceptos que hemos aprendido $\mathrm{y}$, quizás, comunicamos mecánicamente, pero que, según expondremos, podemos emplear de modo diferente. Esta será la tarea que asumiremos en las siguientes líneas, no sin antes precisar que nuestra investigación se centrará en el discurso punitivo que se originó con el nacimiento del Estado Contemporáneo, el cual, con algunas modificaciones, sigue vigente hasta nuestros días. Quedando claro cuál es nuestro propósito comencemos revisando la idea de deconstrucción.

\section{PALABRAS CLAVES}

Deconstrucción, discurso punitivo, hospitalidad, imaginación criminológica.

\begin{abstract}
The objective of this research work is to introduce a different way of thinking about contemporary punitive discourse, for this we will use deconstruction as a strategy to analyze, reveal and redefine it. What we propose is to reflect on some words, ideas and concepts that we have learned and, perhaps, we communicate mechanically, but that, as we will explain, we can use differently. This will be the task that we will assume in the following lines, but not before specifying that our research will focus on the punitive discourse that originated with the birth of the Contemporary State, which, with some modifications, continues to this day. Being clear what our purpose is, let's start by reviewing the idea of deconstruction.
\end{abstract}

\section{KEYWORDS}

Deconstruction, punitive speech, hospitality, criminological imagination. 


\section{¿QUÉ ES LA DECONSTRUCCIÓN?}

Desde el punto de vista filosófico la deconstrucción se desarrolla a partir del pensamiento del filósofo francés Jacques Derrida (1967), re significando el concepto destruktion, creado por el filósofo alemán Martin Heidegger (1927). Sin embargo, cuando Derrida concibe a la deconstrucción -explicada de forma muy simple- no se refiere a destruir sino a desfragmentar, descomponer, desestructurar. Podemos decir que es una crítica de los conceptos, los cuales no podemos eliminar porque los necesitamos para poder pensar. Por lo tanto, deconstruir no es destruir.

Ahora bien, resulta incoherente definir la deconstrucción, porque hacerlo es reducirlo a un concepto, algo totalmente contrario a su propósito. Sin embargo, solo para efectos de este trabajo de investigación señalaremos que deconstruir es hacer una revisión profunda de las afirmaciones de un texto o discurso, para lo cual es importante prestar atención al lenguaje y a todas las implicancias de éste. Es decir, revisar todos los conceptos y procesos que se han utilizado para construir el sentido afirmativo de un discurso, y que han permitido que se instaure como un conocimiento válido. O sea, comprender los supuestos que hicieron que este paradigma se afirme o se instituya como verdad. Entonces, a partir de esta comprensión podremos identificar la posibilidad de otras verdades.

La deconstrucción se identifica, así como una práctica filosófica que cuestiona ideas, conceptos, valores, hábitos, costumbres $\mathrm{y}$ sentidos. Busca, en definitiva, quitar los sedimentos de los discursos para poder entender por qué pensamos lo que pensamos, hacemos lo que hacemos y, decimos lo que decimos. Posibilita encontrar cuáles han sido los mecanismos puestos en marcha para que hoy seamos lo que somos; lo cual constituye el primer paso para poder transformar nuestra realidad.

Derrida inicia su tarea deconstructiva denunciando la existencia del logocentrismo.

El logocentrismo es una creencia cultural incorporada a nuestra manera de ver las cosas que considera que el orden que existe en nuestras representaciones no se puede cuestionar. Presupone una presencia tras el lenguaje, un compromiso ontológico, que garantiza la estabilidad de los procesos, la simetría del universo y la regularidad de los fenómenos. Gracias a este mecanismo confiamos en que tras las palabras habla, se manifiesta la razón o verdad universal porque estamos seguros de que la escritura es el vehículo fiable para transmitir información, comunicar ideas y emociones. Lamentablemente en la experiencia los fenómenos inestables o disipativos son hegemónicos, el universo no es simétrico sino caótico y lo constante es lo aleatorio o azaroso (Huamán, 107).

Por ello, Derrida da suma importancia a la manera como se escriben los textos o discursos, destacando la polifonía de la escritura y la ambivalencia de los conceptos. Debemos dejar en claro que la deconstrucción no es un método sino una actitud filosófica de interpretación de textos, una hermenéutica. Derrida advierte que el primer problema que se tiene al momento de interpretar un texto es asumir que existen ideas principales y secundarias dentro de él, señalando que hay que desechar esta jerarquía binaria o dual que limita la lectura del texto, ya que todo orden puede invertirse.

Precisa que todo texto no tiene solo una voz, sino que está compuesto de múltiples voces que se entraman, y que ofrecen nuevas posibilidades de lectura, por tanto, no hay que excluir a las otras voces sino, por el contrario, integrarlas. La multiplicidad de voces dentro de un texto nos muestra todas las fricciones y grietas dentro de él. Por ende, resulta arbitrario otorgarle un único sentido al texto.

En este orden de idas, y recordando a Michel Foucault (1977), podemos evocar la relación entre poder y saber que nos propone. Para el filósofo francés todo saber supone una instancia de poder desde la cual se busca naturalizar todo conocimiento. Lo que significa dejar de pensar al poder en términos represivos para comenzar a pensarlo en términos de normalización. De esta manera, se ejerce poder normalizando una única forma de pensar cualquier tópico del saber. Reduciendo todas las posibles interpretaciones de un texto a uno solo, y esa lectura, es la que se encuentra al servicio del poder que lo valida. Entonces, cuando se normaliza un único discurso como válido también se normalizan a los demás discursos como inválidos o anormales, o lo que es peor, como falsos. 


\section{REVISANDO DE ALGUNOS CONCEPTOS SIGNIFICATIVOS}

En este apartado, queremos (des)cubrir el origen de algunas palabras que, para nuestro propósito, resultan significativas. Empezaremos con la palabra crimen, la cual se forma de la unión de la palabra indoeuropea $k r e i$, que significa separar o diferenciar, con el sufijo en latín men que significa instrumento, medio o resultado, es decir, el crimen resulta ser el instrumento o medio que sirve para separar o diferenciar. Entonces, el crimen sirve para diferenciar al culpable del inocente, al bueno del malo, del delincuente.

Delincuente se origina del verbo latino delinquere, que es un prefijado con de-sobre el verbo linquere, que significa dejar o abandonar, es decir, el delincuente obra por abandono, deja de cumplir la norma, y en consecuencia, falta a una norma. Es decir, al delincuente se le diferencia porque falta a una norma. Y quizás (solo quizás) lo hace porque también algo le falta. Lo peculiar es que, así como el delincuente abandona la norma, pareciera que, como están las cárceles actualmente en el Perú, a él también se le abandona a su suerte en ella.

El delincuente, al faltar a la norma (comete un delito) origina un conflicto, palabra que viene del latín conflictus, formada por la unión de dos palabras con, que significa unión, y flictus, que significa golpe, es decir, el conflicto es el golpe a la unión, a la unidad, al orden. Y también, es una diferencia, una controversia, disensión u oposición entre dos personas. Que paradójico que el conflicto surja de la unión de dos palabras, nos querrá quizás revelar que el conflicto en realidad nos une, que el conflicto es previo, que nuestras diferencias son las que nos unen, o que, posiblemente, gracias a que somos diferentes podemos ser iguales.

En resumen, el conflicto surge porque el delincuente irrumpe con su diferencia, con su carencia, con su falta. Irrumpir viene del latín irrumpere cuyos componentes léxicos son in, que significa hacia dentro, y rumpere, que significa romper, es decir, entrar rompiendo un lugar, entrar golpeando y destruyendo un espacio. Y si el delincuente entra es porque viene desde afuera, es decir, desde los márgenes irrumpe en nuestro espacio, o sea, queda claro que existe un adentro y un afuera, pero, ¿cuál es el límite entre ambos espacios? $\mathrm{y}$, sobre todo, ¿quién lo establece?, ¿a quién se deja afuera y a quién adentro?, ¿quién queda el margen?

Si el delincuente viene desde afuera, es un extranjero, y como tal, resulta diferente, posee otras costumbres y creencias, otras verdades, o sea, ello demostraría que hay dos o más verdades no solo una, hay diferencia, es por ello que surge el conflicto. Y esa otra verdad, la del otro, no satisface mis necesidades, no me cierra, no me resulta útil o funcional, desequilibra lo que espero, altera el orden que he establecido, pone en peligro mi seguridad.

Entonces, la pregunta es: ¿cómo solucionamos el conflicto que ha surgido cuando el otro irrumpió y perturbó mi tranquilidad?, cuando golpeó y rompió nuestro orden -golpe viene del latín fligere, palabra que significa aflicción, dolor, pena. ¿Será quizás la solución también golpearlo?, es decir, causarle el mismo dolor, pena o aflicción que nos causó. ¿Sería lógico sostener que otro golpe, uno quizás más fuerte, pueda solucionar el conflicto que ha surgido? Si ello fuere así, otra interrogante que surge es: ¿quién puede golpear más fuerte que el delincuente?, o, mejor dicho, ¿quién está autorizado a dar ese golpe y que todos confiemos en que servirá para solucionar el conflicto existente?

\section{EL DISCURSO PUNITIVO Y SUS ELEMENTOS}

La palabra discurso proviene del latín discursus que significa serie de palabras con coherencia lógica y gramatical con las que se expresa los que se siente o se piensa. Sus componentes léxicos son: el prefijo dis -divergencia, separación múltiple-, y cursus -curso, camino, recorrido, carrera. Entonces, se trata de una acción comunicativa cuyo objeto es transmitir una información y, por lo general, convencer a los destinatarios de ésta.

Podemos señalar tres perspectivas del discurso, las cuales se enlazan entre sí para permitirnos comprender su complejidad. La primera analiza la estructura del texto del discurso. La segunda se enfoca en su estructura social y cultural, como interacción social comunicativa de las personas en contextos específicos. Y la tercera, desde una noción cognitiva, construye las relaciones entre el contexto social y las acciones comunicativas. Los discursos no tienen un 
sentido intrínseco, sino que se lo dan quienes lo emplean. Son las creencias personales y compartidas de quienes interactúan las que producen y reproducen el discurso. Por tanto, los discursos son construcciones (mentales) de cada persona, los mismos que otorgan sentido al texto y la interacción lingüística, y a los propios hechos sociales sobre los que trata el discurso.

A nuestro juicio, es posible identificar elementos comunes en relación a todo discurso: a) el escritor, b) la gramática, c) el texto, d) las ideas principales, e) la lógica y las razones que sustentan las ideas principales, $\mathrm{f}$ ) la interpretación oficial, g) una voz que habla el discurso -el comunicador-, $h$ ) de qué o quién se habla, i) el receptor, y j) un fin u objetivo que busca su legitimación.

En el caso del Derecho Penal, el término discurso suele emplearse para expresar los valores, estrategias e ideologías que contienen los textos $\mathrm{u}$ otras formas de creación de significado, sin embargo, no se le presta atención al análisis de lenguaje, es decir, no se examina cómo las estructuras del texto contribuyen a un modelo político criminal.

Podemos definir al discurso punitivo como el conjunto de textos que, de manera razonada y sistemática, exponen y explican la ideología, doctrina o dogmática que sostiene la tesis que, toda persona que ha cometido un crimen debe ser sancionada con la imposición de una pena, con la finalidad de proteger la estabilidad del ordenamiento jurídico, defender a la sociedad, y resocializar al penado.

En este orden de ideas, el discurso punitivo está conformado por los siguientes elementos:

a) El escritor es quien ejerce el poder punitivo, aquellos que elaboran las normas penales: poder legislativo, y poder ejecutivo excepcionalmente.

b) La gramática son los principios generales del Derecho Penal que permiten la configuración de un ordenamiento jurídico penal.

c) El texto es la ley o norma penal.

d) Las ideas principales son los dogmas o instituciones que constituyen la esencia del discurso punitivo. e) La lógica y las razones que sustentan sus ideas principales son las argumentaciones de los dogmáticos penales que justifican el discurso punitivo, denominadas también doctrinas penales.

f) La interpretación oficial son las resoluciones judiciales denominadas jurisprudencias.

g) Quienes comunican el discurso son las agencias del sistema penal: Policía, Ministerio Público, Poder Judicial, Instituto Penitenciario, etc.

h) De qué o quién se habla son la pena, el delito y el delincuente.

i) El receptor del discurso es la sociedad en su conjunto.

j) El fin que legitima el discurso, son las funciones o fines de la pena: prevención, protección y resocialización.

\section{DECONSTRUYENDO EL DISCURSO PUNITIVO CONTEMPORÁNEO}

Con el surgimiento del "Estado social contemporáneo", se fortalece la idea de que el poder punitivo, fundamentado y limitado por el contrato social, resulta ser una de las formas idóneas para solucionar los conflictos que surgen de la convivencia social. Para ello, se establece que cuando un ciudadano comete un delito, violando las normas establecidas, el Estado adquiere la facultad de privarlo de sus derechos fundamentales y castigarlo. Así, el poder punitivo se convierte en la facultad que tiene el Estado para penar a quien comete un crimen, y la pena sirve para que quien violó las normas no vuelva hacerlo, y a su vez, para disuadir a los demás a no imitarlo, pues, acabaría pasándoles lo mismo.

De este modo, el poder del Estado para reprimir (poder negativo) se naturaliza, y comienza a reproducir un discurso que normaliza la imposición de la pena privativa de libertad como el mejor mecanismo para la solución de los conflictos (poder positivo). Este discurso, gracias a la dogmática penal (saber penal), se instala como única verdad, y la prisión resulta ser su principal instrumento. Tenemos tan internalizado este discurso que parece que fuera inherente al ser humano, pero no es así, ya que el poder punitivo existe hace muy poco 
tiempo. Por tanto, la afirmación de que existió siempre resulta falsa, la humanidad transitó mucho tiempo sin conocer el poder punitivo, éste ha aparecido y desparecido en distintos momentos de la historia.

Cómo argumentaban Hobbes y Locke en el siglo XVII y luego Rousseau en el siglo XVIII, la sociedad consiste en individuos que se unen bajo el acuerdo de un contrato, formando así la sociedad. Bajo este esquema, violar la ley no constituye un ataque contra una persona, sino una violación del contrato social, por lo que la víctima no es una persona en particular, sino la sociedad en su totalidad. Quien tiene derecho de respuesta no es una persona, sino la sociedad, y el criterio con el que responde no es la integridad de esa persona, sino la humanidad que todas las partes del contrato comparten.

Para los intelectuales franceses de la época, el término "sociedad" no hacía referencia a una abstracción, sino a una realidad, al cuerpo social. Si te quemas un dedo en el fuego, lo razonable no es cortarte la mano, sino tratar de curarlo. De la misma manera, no tiene sentido reducir a cenizas a un miembro del cuerpo social, sino que hay que corregirlo y recuperarlo para el bien del cuerpo social.

Sin embargo, éste discurso deja de lado a la víctima del delito, pues, al señalar el Estado que la comisión del delito se sanciona por constituir una infracción al contrato social, le expropia el conflicto a la víctima, y toma con poca importancia la reparación del daño sufrido por él. Esto produce que el conflicto surgido quede sin solución, ya que el agraviado no ve reparado el daño sufrido por la comisión del delito en su contra. Por ello, cuando el poder punitivo restituya el conflicto a la víctima dará paso a un modelo de solución de conflictos, y dejará de existir, pues su esencia se ha estructurado en torno a la exclusión de la víctima. A partir de la exclusión de la víctima, el proceso penal dejó de ser un método para resolver conflictos entre las partes, y se convirtió en un ejerció de poder punitivo del Estado con el propósito de imponer un castigo al delincuente.

Junto a este discurso punitivo surgió la interrogación o inquisición del procesado como método para obtener la verdad de los hechos. Por eso, si el procesado no quería confesar se le torturaba hasta hacerlo declarar. Así, el poder constituye el saber, el saber se obtiene interrogando a los procesados en base al poder que se quiere ejercer sobre ellos. No hay diálogo sino interrogatorio violento. De esta manera, del poder punitivo surge el saber inquisitorial para disciplinar a los ciudadanos de manera vertical. En ese momento, resultaba necesario para el poder político disciplinar a la sociedad con el objetivo de eliminar a los ciudadanos disfuncionales. Y ello no se podía conseguir matando a los delincuentes sino encerrándolos en prisión. Además, con la ejecución pública de las penas de suplicio (de muerte), se emparejaba al verdugo con el criminal y a los jueces con unos asesinos, se invertía en el momento final los papeles, y se mostraba al condenado como un objeto de admiración o compasión.

Nace así la pena privativa de libertad con fines de "resocialización" como una pena "más humana". Como apunta Foucault (1976): "La ejecución de la pena pasa a convertirse en un sector autónomo, un mecanismo administrativo del cual la justicia se desentiende liberándose así de su sorda desazón por un escamoteo burocrático de la pena" (Pág. 19). La ejecución de la pena se convertirá en la parte más oculta del proceso penal, así, la ciudadanía pierde de vista a las personas que son enviadas a prisión. Además, surge una nueva justificación teórica que libera a los jueces de sentirse mal por enviar a prisión a los delincuentes., se dice que la pena no consiste en castigar o sancionar, sino sirve para corregir, curar o reformar al condenado.

No obstante, esta tecnología política del poder punitivo, aplicada sobre el cuerpo y alma de los condenados, debe ser analizada como fenómeno social, situándola en su campo de funcionamiento para demostrar que la pena no es únicamente la sanción ante la comisión de un delito con el objeto de reprimir, prevenir o aislar, sino que tiene como propósito el mantenimiento de un sistema punitivo para la producción de "cuerpos dóciles". Así, el ejercicio de poder punitivo constituye al ser humano. El sujeto (cuerpo y alma) es producto de una evolución genealógica, su mecanismo de constitución o construcción histórica es la disciplina, ésta funciona en diversos espacios sociales, pero en ninguno de forma más clara que en la prisión, pues, revela una cuidadosa administración de la conducta. 
Por eso Foucault cuestiona intensamente este discurso punitivo. En vez de progresar hacia la libertad de las personas sometidas a la pena, los mecanismos que identifica en el entorno carcelario, los cuales también operan en las fábricas, las escuelas y los hospitales, constituirán más bien espacios de aislamiento en los que, en vez de hacerte libre, la verdad constituye las barras de tu celda, pues en las cárceles se inscriben ideas en las mentes de los presos sometiéndolos de por vida al poder que impone ese saber inscrito.

En esta tecnología política del poder punitivo la pena funciona como un símbolo, y como sabemos todo símbolo representa una idea, la idea tras la pena es el delito por el que se castiga, sin embargo, el receptor no es sólo es el delincuente sino la sociedad en general. No obstante, un libro cerrado no puede leerse, por tanto, una pena que no puede verse no generará efectos en la sociedad. En consecuencia, no tiene sentido que la pena se ejecute dentro de los muros de una prisión sin que nadie la pueda ver, por ello, para que la pena tenga un efecto restaurador, lo óptimo sería que el infractor la cumpla en contacto con la sociedad, en lugar de encerrársele debiera realizar obras públicas en beneficio de la comunidad, haciendo visible la reparación del daño social producido por su delito. Así, la sociedad se favorecía de su trabajo y de la lección que comunicaba. Con un sólo acto se resocializaba y se compensaba el daño a la comunidad.

Por eso, no se equivoca Foucault al señalar que la gran innovación de la prisión no es ni el encierro del delincuente ni el trabajo que hace. No busca aislarlo, ni que sirva para confirmar la vigencia de la norma jurídica, como erróneamente sostiene el sobre estimado profesor Günther Jakobs. Sino, lo que busca es su transformación, tanto del cuerpo cómo del alma, mediante la aplicación precisa de técnicas de conocimiento y poder. No se trata de retribución ni de prevención general positiva, sino de la producción de lo que Foucault llama "cuerpos dóciles".

La forma a través de la cual se lleva a cabo esta transformación es lo que Foucault describe como una vigilancia continua y total, por ello, la prisión es una tecnología disciplinaria del cuerpo para la modificación del alma de los condenados. Asimismo, resulta transcendental entender que la prisión, para
Foucault, sirve simplemente de ejemplo, ya que el mismo fenómeno puede observarse en otras instituciones como el hospital, la escuela, o la empresa. Pues, Foucault está interesado en describir a la sociedad como un instrumento disciplinario.

Entonces, queda claro que el poder punitivo se encarga de controlar, y su saber, el discurso punitivo, se encuentra al servicio de los controladores quienes utilizan este sistema o mecanismo punitivo para excluir del poder y marginar socialmente a disidentes, minorías étnicas, inmigrantes, minorías sexuales, personas con necesidades especiales, etcétera. Así, el poder punitivo es la punta de lanza de la jerarquización verticalizante que nutre todas estas discriminaciones y violaciones de la dignidad humana. Por otro lado, no hay que perder de vista que los discursos no solo expresan lo que dicen sino también lo que ocultan y que los operadores del saber no sólo se manifiestan en lo que ven sino también en lo que dejan de ver.

Es evidente que el poder punitivo opera siempre selectivamente, se distribuye de acuerdo a la vulnerabilidad y responde a estereotipos, los cuales se construyen de las imágenes negativas cargadas con todos los prejuicios que contribuyen al sostenimiento cultural de las discriminaciones. A ello obedecen las características comunes de los presos, que pueden ser clasificados según los prejuicios que determinaron su selección. Por ello, resulta insostenible e inconcebible que el instrumento por excelencia para la discriminación pueda llegar a ser un mecanismo para eliminar la misma.

Además, teniendo en cuenta las manifestaciones empíricas del sistema punitivo podemos señalar que: a) la pena es violencia institucional de las necesidades fundamentales de individuos vulnerables, mediante la acción legal o ilegal de los funcionarios del poder punitivo; b) las agencias penales no representan ni tutelan los intereses de la sociedad sino de los grupos dominantes y privilegiados; c) la justicia penal es altamente selectiva, criminaliza a las personas con más carencias socioeconómicas, pese a que observamos la comisión de delitos graves por individuos pertenecientes a las clases dominantes; d) no soluciona los conflictos sociales sino los agravan aún más; e) por la forma en que se ha organizado y 
funciona no puede cumplir con las funciones que declara en su discurso oficial, las cuales responden a ideas utilitaristas de la pena.

Entonces, pareciera a primera vista que el sistema punitivo ha fracasado rotundamente, pues no previene la comisión de delitos, no protege los intereses de la comunidad, y menos aún resocializa al condenado. Sin embargo, develando las funciones subterráneas del poder punitivo podemos comprobar que ha sido un éxito, las cuales explican su sobrevivencia histórica pese al incumplimiento de las funciones oficiales declaradas. $\mathrm{Y}$ es que el poder punitivo y su discurso sirven, sobre todo, como hemos venido señalando, para discriminar y etiquetar los conflictos sociales existentes como "criminalidad", es decir, como un problema que depende de las características personales y conductas desviadas y anti sociales de los delincuentes.

Asimismo, la prisión sirve para la reproducción de los "delincuentes", aquellas personas reclutadas de los estratos más débiles y marginales de la sociedad, y para representar como normales las relaciones de desigualdad existentes en la sociedad. Por ello, la pena se presenta como violencia útil para el mantenimiento de un sistema socioeconómico que conviene a quienes detentan el poder económico, constriñendo las necesidades de la mayoría de individuos.

Por otro lado, podemos encontrar diversas aporías $^{1}$ en las teorías de la pena. Según Immanuel Kant, seguido por Günther Jakobs, la pena justifica su imposición en la defraudación de una norma jurídica. Sin embargo, existen diversas defraudaciones normativas en otras ramas del Derecho que permanecen exentas de castigo. También, según Jakobs, la pena tiene una función de prevención general positiva, pues, sirve para restablecer la vigencia de la norma, para ello, niega al delincuente que negó la existencia de la norma cuando la defraudó cometiendo un delito.

No obstante, un análisis simple demuestra que toda persona que comete un delito sabe de su existencia y quiere su realización (delito doloso), o inobserva un deber de cuidado que

1 Una aporia es un enunciado que expresa o que contiene una inviabilidad de orden racional. Es un término que sirve para señalar una contradicción insoluble que se encuentra en cualquier razonamiento. sabe debe cumplir (delito culposo), por ende, al cometerlo asume la probabilidad de ser sancionado. De ello se deduce que el agente no niega la existencia del delito, por el contrario, lo afirma al aceptar que podría ser sancionado. En consecuencia, queda totalmente claro que al cometer el delito y asumir una posible consecuencia jurídica, afirma su existencia, no resultando necesaria la imposición de la pena para negar a quien jamás negó con su conducta delictiva la existencia del delito, menos aún, para restablecer la vigencia de una norma que nunca perdió su obligatoriedad.

Otra función de la pena es la prevención especial positiva, es decir, la resocialización. Palabra que no se encuentra en el diccionario de la Real Academia Española pero que, sin embargo, es repetida incansablemente por cuanto libro o profesor de Derecho Penal existe. La palabra que sí existe es socialización, la cual significa, acción o efecto de socializar, es decir, adaptar a un individuo a las normas de comportamiento social.

Es difícil afirmar que una persona aislada de la sociedad, vale decir, dentro de los muros de una prisión, pueda ser "resocializada". La socialización es una acción, es el resultado de un hacer y no de un escuchar, leer u observar, no se aprende teóricamente sino empíricamente, es decir, a través de experiencias de vida. Una persona confinada junto a otras que también necesitan "resocializarse" va aprender de ellas, por tanto, experimentará sus carencias de socialización. En consecuencia, no logrará estar adaptado a las normas de comportamiento social sino, al contrario, estará más inadaptado debido a las interacciones con otras personas que también necesitan "resocializarse", y también, porque ha vivido algunos o muchos años aislado de la sociedad. En este orden de ideas, sostener que una persona en la cárcel pueda ser "resocializada" resulta una aporía.

Por otro lado, la ontología o metafísica general es la rama de la Filosofía que estudia al ser y sus propiedades trascendentales, a la existencia de los entes, etcétera. Martín Heidegger en su obra Ser y tiempo, escrita en el año 1927, planteó la diferencia ontológica, señalando que el ser se diferencia del ente, pues, el ser de un ente no es lo mismo que el ente, el ser de un ente alude a su existencia, "a algo que es", en suma, el ser es previo y no depende del ente que existe. 
Heidegger también señala en Ser y tiempo que resulta necesario preguntarnos por el sentido del ser, pues los filósofos que lo han precedido se han olvidado de esta pregunta tan primordial y necesaria. Coincidimos con Heidegger en que la pregunta por el ser debe preceder el estudio de cualquier disciplina, ella constituye la pregunta fundamental a partir de la cual se estructurará cualquier área de conocimiento humano.

Heidegger (2003) afirma con mucha razón:

Toda pregunta es una búsqueda, y todo buscar debe estar guiado previamente por aquello que se busca. Preguntar es buscar conocer el ente en lo que respecta al hecho de que es y a su ser-así. La búsqueda cognoscitiva puede convertirse en "investigación", es decir, en una determinación descubridora de aquello por lo que se pregunta. Todo preguntar implica, en cuanto preguntar por..., algo puesto en cuestión. Todo preguntar por... es de alguna manera un interrogar a... Al preguntar le pertenece, además de lo puesto en cuestión, un interrogado. En la pregunta investigadora, específicamente teorética, lo puesto en cuestión debe ser determinado y llevado a concepto. En lo puesto en cuestión tenemos entonces, como aquello a lo que propiamente se tiende, lo preguntado, aquello donde el preguntar llega a su meta. El preguntar mismo tiene, en cuanto comportamiento de un ente - del que pregunta- su propio carácter de ser. El preguntar puede llevarse a cabo como un "simple preguntar" o como un cuestionamiento explícito. Lo peculiar de este último consiste en que el preguntar se hace primeramente transparente en todos los caracteres constitutivos de la pregunta misma que acaban de ser mencionados. (Página 26)

En este orden de ideas, sostenemos categóricamente que los estudiosos del Derecho Penal se han olvidado de la pregunta por el ser de la pena, y tan sólo se han limitado en sus investigaciones a definir sus fines y funciones. No poniendo debida atención a la institución más importante del Derecho Penal, la cual le otorga la mitad de su denominación. Entonces, hagamos nosotros la pregunta: ¿qué es la pena? La pena es dolor, tormento, sufrimiento o sentimiento corporal.

Entonces, caemos en cuenta que hemos construido una rama del Derecho sobre la base del dolor o sufrimiento humano. Y que, quizás, el olvido de la pregunta por el ser de la pena no fue por negligencia sino por conveniencia. Fue con la intención de no demostrar que el Derecho
Penal es un oxímoron, es decir, la combinación, en una misma estructura sintáctica, de dos palabras o expresiones de significado opuesto que originan un nuevo sentido. Sin embargo, este nuevo sentido es una paradoja, la cual se ha refugiado en concepciones utilitaristas de la pena, que, como ha quedado demostrado, tampoco son satisfactorias en la realidad.

Por miedo a ésta respuesta, desde hace algún tiempo, el Derecho Penal se ha refugiado en la dogmática penal, construyendo dogmas y teorías puras del Derecho Penal, sin embargo, a nuestra humilde opinión escogió un camino erróneo, pues, el conocimiento dogmático no es científico, por eso, las teorías que ha postulado están muy alejadas de la realidad y al verificarse científicamente demuestran inconsistencias e incoherencias.

Por dogmático debemos entender a algo indiscutible ${ }^{2}$, fidedigno, innegable, que no admite réplica o cuestionamiento. Como dogmático definimos todo lo perteneciente o relativo a los dogmas, es decir, el conjunto de fundamentos o principios por los que se rige una religión, doctrina ${ }^{3}$, saber o sistema normativo determinado. La dogmática jurídica es una disciplina perteneciente al Derecho, que consiste en un sistema de carácter formal compuesto por dogmas jurídicos. Tales dogmas, según el método dogmático, se extraen ${ }^{4}$ del contenido de las normas jurídicas positivas, utilizando la abstracción, y siguiendo una serie de operaciones lógicas ${ }^{5}$ que otorgan a la

2 No es un conocimiento científico sino dogmático. El conocimiento dogmático es un conocimiento como creencia individual o colectiva relacionado con tradiciones orales, códigos, o actos de autoridades religiosas. Este conocimiento se acepta y admite sin réplica, sin cuestionamientos, dudas, ni contradicciones. No es posible (ni se admite) someterlo a pruebas científicas (constatación a través de la experiencia, sentidos) o razonamientos lógicos. Implica suponer que existen fuerzas superiores, sobrenaturales (Dios) o personalidades y autoridades omnipotentes que interpretan una realidad que sólo ellos pueden explicar. Este conocimiento se adquiere, propaga y conserva por vía oral, cultos religiosos o códigos doctrinales.

3 La doctrina es un conjunto de ideas o concepciones teóricas enseñadas como verdaderas por un autor o grupo de autores. Puede tener una dimensión ideológica que puede ser política, legal, filosófica, científica, social, etc. En el ámbito jurídico, la doctrina jurídica es la idea del derecho que sustentan los juristas. Son directivas que no son directas para resolver una controversia jurídica, pero indican al juez como debe de proceder para descubrir directiva o directivas decisivas para resolver la cuestión en debate. Ayuda en la creación del ordenamiento jurídico.

4 Entonces ¿los dogmas se extraen de las normas o constituyen a las normas?

5 Un proceso al que podríamos denominar la reducción dogmática. 
dogmática jurídica un carácter eminentemente sistemático ${ }^{6}$. En contraposición al método exegético, en el que la interpretación de la norma se sustenta en el sentido de las palabras reflejadas en el derecho positivo, el método dogmático se atiene a los dogmas ${ }^{7}$ que se han logrado extraer como instrumento principal para interpretar el sentido de la norma jurídica.

Por tanto, la dogmática jurídica se centra en el estudio del contenido normativo de las leyes, de todo un sistema jurídico o de sectores concretos de cada sistema jurídico. Así, la dogmática jurídica se basa fundamentalmente en las fuentes formales que integran el ordenamiento jurídico, vale decir:

a) La ley: constituye, en la mayoría de los ordenamientos jurídicos modernos, fuente primordial y directa del derecho; y

b) Los principios generales del derecho (dogmas): son los enunciados normativos más generales que, a pesar de no haber sido integrados formalmente al ordenamiento jurídico vigente, se entiende que son parte de él, porque sirven de fundamento a otros enunciados normativos particulares, o bien recogen de manera abstracta el contenido de un grupo de ellos. Son conceptos o proposiciones de naturaleza axiológica o técnica que informan la estructura, la forma de operación y el contenido mismo de las normas, grupos normativos, conjuntos normativos y del propio derecho como totalidad. Estos principios son utilizados por los jueces, los legisladores, los creadores de doctrina y por los juristas en general, sea para integrar lagunas legales o para interpretar normas jurídicas cuya aplicación resulta dudosa.

Entonces, el conocimiento dogmático es un conocimiento inconcuso, por ende, no puede ser puesto en verificación por la ciencia, ya que es incuestionable. Estando así las cosas poco se puede avanzar para con la construcción de una Ciencia Penal, pues, insistiendo en el camino de la dogmática penal solo nos encontraremos entre cuatro paredes formadas por dogmas

\footnotetext{
$6 \mathrm{Y}$ si en lugar de señalar que se extraen de las normas jurídicas, decimos que los dogmas se emplean para constituir o crear a las normas jurídicas a través del método deductivo (siendo lo general el dogma y lo particular la norma jurídica positiva).

7 También llamados principios doctrinales.
}

incuestionables, y el Derecho Penal lejos de ser coherente con las cuestiones sociales, políticas, psicológicas, etcétera, que busca regular, perderá eficiencia y eficacia práctica.

Así las cosas, la fuerza de los hechos nos ha demostrado que los principios o dogmas del Derecho Penal no se cumplen a cabalidad. Hoy, los principios fundamentales, sobre los cuales se construyó el discurso punitivo contemporáneo, no se respetan como dogmas. El principio de legalidad se ve arrinconado cada vez por más leyes penales abiertas y en blanco; el principio de ofensividad o exclusiva protección de bienes jurídicos por delitos de peligro abstracto o sin bienes jurídicos concretos; el principio de proporcionalidad de las penas con sanciones cada vez más excesivas en comparación con el contenido del injusto.

En resumen, el Derecho Penal no es ni mínimo, y menos aún, de última ratio. Cada vez se criminalizan más conductas, o las ya existentes amplían sus elementos descriptivos o normativos. Y por si no fuera poco se ha vuelto una moda teórica, hace algunos años la discusión era dónde ubicar el dolo (culpabilidad o tipicidad), luego fue la famosa teoría de la imputación objetiva de Claus Roxin y Günther Jakobs, y ahora, estamos en la era del Criminal Compliance. Bueno fuera que estas discusiones sirvieran para reducir los índices de criminalidad existentes, o para que la pena realmente funcione para algo, sin embargo, tan sólo valen para que los "dogmáticos" penales escriban libros que decoren los estantes de las librerías o bibliotecas, o den clases de cursos de especialización, diplomados o estudios de posgrado sobre dicha temática.

Así, tenemos un Derecho Penal lleno de mitos y de modas que lo único que revela es que la pena ha muerto, por tanto, el Derecho Penal es una disciplina tanatológica, pues, se encarga de un ente muerto. No obstante, el crimen sigue vivo, lo encontramos en la calle, en los hogares, en las empresas y, sobre todo, en las entidades públicas. Necesitamos estudiarlo de manera empírica para comprenderlo y encontrar respuestas eficientes y eficaces para reducirlo a límites tolerables, ya que decir que lo vamos a eliminar demostraría un retorno al populismo punitivo mediático y electoral del que estamos todos hartos. 
De lo antes señalado es evidente que el discurso punitivo contemporáneo debe ser deconstruido. Detrás de éste se esconden poderes que ejercen funciones subterráneas para manipularlo a su conveniencia. Esto se consigue, sobre todo, gracias a la desidia y colaboración de sus actores oficiales, es decir, las agencias penales estatales, quienes en lugar de velar por que opere eficiente y eficazmente con el objetivo de alcanzar un bienestar general social lo han utilizado como herramienta de gobernanza en beneficio de intereses crematísticos individuales o sectoriales.

De esta manera, tras realizar el análisis se devela que:

a) Quienes escriben el discurso punitivo contemporáneo son los poderes económicos y/o financieros totalitarios, quienes lo emplean como una herramienta o instrumento de gobernanza, con el único propósito de reproducir el sistema neoliberal que los beneficia en perjuicio de los vulnerables.

b) Se evidencia que los principios del Derecho Penal han sido relativizados, lo que ha forjado un ordenamiento jurídico penal cada vez más normativista e idealista (neo kantista), el cual le ha dado la espalda a la realidad social y política.

c) La ley penal tiene textos ambivalentes, los cuales constituyen las grietas necesarias para su deconstrucción.

d) Insistir en la dogmática penal es renunciar a un Derecho Penal científico, conlleva a encerrarlo en configuraciones lógicoabstractas sin realidad, las cuales no sirven para reducir el fenómeno de la criminalidad, pues, no han sido formuladas observando la interacción social ni verificando empíricamente su eficacia. De esta manera, se aprecia que la dogmática penal se ha vuelto la religión de muchos penalistas, $\mathrm{y}$ algunos parecen fundamentalistas, ya que se niegan a observar la existencia de múltiples conocimientos científicos fuera de ella.

e) La doctrina penal sólo interpreta las normas jurídicas convenientes y no las incómodas, a estas últimas las oculta y margina. Con ello, el discurso se va decantando por posiciones "autorizadas" que no incluyen aquellas grietas legales que podrían servir para generar un discurso punitivo alternativo más humano e inclusivo.

f) Las agencias del sistema penal comunican un discurso diferente al que se encuentra escrito en el texto legal. Se comunica para imponer y no para dialogar, no se escucha al "otro", es decir, al "delincuente", no se le asiste ni se aprende de él para prevenir nuevos crímenes.

g) El "delincuente" solo es utilizado para la reproducción y el mantenimiento del discurso punitivo, además, es invisibilizado, aislado por la seguridad de todos sin propósito alguno.

h) Los fines que legitiman el discurso punitivo no se cumplen, la pena no previene, protege ni resocializa.

\section{DE LA DIFERENCIA A LA DEFERENCIA}

Creemos que desde su origen la imposición de la pena de prisión ha generado la diferenciación del penado. Y no sólo lo ha diferenciado sino también lo ha diferido en tiempo y espacio, pues ha postergado su vida suspendiéndola por el tiempo que dura la pena de prisión, $y$, además, lo ha aislado de la sociedad enviándolo a la cárcel, con la falsa promesa de que ahí, aislado de ella, va a "resocializarse". Así, el delincuente es etiquetado y estigmatizado gracias al discurso punitivo, pues, desde su ingreso a la cárcel será visto como el otro, como el diferente, como un delincuente de por vida.

Pero, ¿podemos pensar a la prisión de una manera diferente?, es decir, ¿hay otra verdad o discurso minoritario, vencido y olvidado, el cual ha sido excluido por el discurso oficial y se encuentra al margen?, ¿cómo lo encontramos?, ¿cómo nos salimos de esta verdad oficial, cerrada hacia lo que está afuera de sus márgenes, de sus límites, de sus definiciones y conceptos?, ¿cómo accedemos a lo diferente de esta verdad?, ¿cómo desmantelamos sus dogmas y sedimentos?, ¿cómo la deconstruimos?, ¿cómo nos damos cuenta de que no hay hechos (cerrados) sino sólo interpretaciones?

¿Cómo nos damos cuenta de que la única verdad es que todo cambia, y que de todo se puede dudar? Que ese discurso instalado no hace lo 
que dice, pues no lo dijo para hacerlo sino para instalarse y normalizarse. Y que, además, sirve de instrumento para gobernar, para producir cuerpos dóciles y económicamente rentables, para eliminar las diferencias, para estandarizar, para aislar e invisibilizar a los otros, porque lo que se invisibiliza es más fácil de olvidar y de atender.

¿Cómo construir una forma diferente de pensar al sistema penal?, ¿cómo relacionarlo con el otro, con el diferente?, ¿tolerándolo?; es decir, comprendiendo su diferencia, pero no aprendiéndola, o sea, aceptando su diferencia, pero manteniéndose distante. O quizás, comprendiendo al otro tan sólo para cambiarlo, es decir, para des-otrizarlo. $\mathrm{O}$, tal vez, mejor sería ser hospitalario con el otro, es decir, brindarle nuestra hospitalidad, comprendiendo que al nominarlo como "otro" se ejerce poder en su contra, y que este ejercicio de poder nos hace responsables de él.

Es decir, dándonos cuenta que más importante resulta defender su otredad que priorizarnos. En el fondo resulta una decisión y elección personal, ya que uno puede ser parte de su propia mismidad o abrirse a la otredad, al aprendizaje del otro. Cuando uno se abre a la otredad viene lo más complejo, pues la exigencia del otro hace que me pelee contra mi propia comodidad. Entonces, la clave es la atención y asistencia del otro, estar abierto a sus necesidades, comprender que el otro siempre tiene la prioridad, ¿difícil?, sí, pero no imposible.

En el castellano andino del Perú la presencia del quechua como lengua sustrato ha generado que exista una indistinción entra las vocales "e" y la "i". Por ello, muchas personas de habla quechua en lugar de pronunciar diferencia pronuncian "deferencia". Creemos que en esta "confusión" en la pronunciación, lo que para muchos sólo sirve para diferenciar o discriminar a quienes proceden de las zonas andinas de nuestro país, se oculta una gran lección, pues deberíamos aprender de esa manera diferente de pronunciar que tienen las personas quechua hablante, $\mathrm{y}$ en lugar de hacer una diferencia hacer una deferencia.

Deferencia procede del latín de-, prefijo que indica movimiento de arriba o abaja, fero, que significa llevar, y encia, que significa la acción o cualidad de un agente. Por eso, la deferencia es un acto de respeto y amabilidad de alguien que se encuentra momentáneamente en una condición de privilegio frente a otro, así, quien está en una mejor posición acude al encuentro del otro para ofrecerle su apoyo, su amabilidad, su hospitalidad. Sin querer imponerse a él, sino, solo para asistirlo y aprender de su diferencia.

Por eso, deconstruir el discurso punitivo para nosotros significa conocer al crimen y a su autor para asistir y no para diferenciar, es decir, para solucionar y no para separar. Solo así, podremos, todos juntos, generar un real giro copernicano, pero esta vez, la solución del conflicto generado por el crimen no se conseguirá des-otrizando al otro a través de la prisión, sino aprendiendo de él, de sus faltas, de sus carencias, es decir, conociéndolo a fondo.

$\mathrm{Y}$ es que no se puede asistir a quien no se conoce, es decir, no se puede asistir al penado si no se busca aprender de su diferencia sin des-otrizarlo. Por ende, si el discurso punitivo siempre ha señalado que con la pena de prisión busca resocializar al penado con la finalidad de prevenir los eventuales crímenes que pudiera cometer, resulta paradójico que, intente prevenir lo que nunca le ha interesado conocer, pues, no se puede prevenir lo que no se conoce. Entonces, resulta más que evidente que, al discurso punitivo nunca le ha interesado prevenir, y que tan sólo lo ha manifestado para ocultarnos su verdadero propósito.

\section{DE LA HOSTILIDAD A LA HOSPITALIDAD}

Las cárceles en el Perú son espacios hostiles para los presos, en ellas existe hacinamiento, falta de atención médica y psicológica, de asistencia social, de alimentación, de aseo y/o higiene, de un alojamiento adecuado, es resumen, en ellas las personas son tratadas inhumanamente, vulnerándoseles su dignidad de manera grave y sistemática. Dichos espacios parecen más un campo de concentración para judíos durante la segunda guerra mundial que, un lugar en donde se procure reeducar, rehabilitar o reincorporar al penado a la sociedad.

Los penados son ocultados de la sociedad en dichos lugares, son confinados a dichos espacios para invisibilizarlos por el tiempo que dure su condena. $\mathrm{Y}$ pese a que existen muchas normas penitenciarias que regulan la manera como deben ser tratados, éstas son 
gravemente incumplidas por el Estado. En la cárcel un interno no puede alcanzar, mantener o recuperar el bienestar físico y mental, menos aún cuenta con servicios médicos básicos o la asistencia social necesaria que permita mantener las relaciones entre él y su familia.

A ello se le suma la poca o nula importancia que recibe la historia de vida del condenado durante el proceso penal, pese a que el artículo 45 del Código Penal establece que:

El juez, al momento de fundamentar y determinar la pena, tiene en cuenta:

a) Las carencias sociales que hubiese sufrido el agente o el abuso de su cargo, posición económica, formación, poder, oficio, profesión o la función que ocupe en la sociedad.

b) Su cultura y sus costumbres. (...)

Sin embargo, hoy los jueces tan sólo se preocupan por el delito que ha cometido, por valorar los medios de prueba que acrediten la existencia de una conducta típica, antijurídica y culpable, para así afirmar que se ha producido un hecho delictivo e imponer una pena. No obstante, dicha pena se impone cual operación aritmética, recurriendo para ello a hacer un check list de las circunstancias agravantes y atenuantes establecidas en el artículo 46 del Código Penal, y luego, a utilizar el famoso "sistema de tercios" establecido en el artículo 45-A del citado cuerpo normativo.

Ante ello, pareciera que los jueces se han convertido en una especie de notarios o verificadores de categorías delictivas teóricas, o peor aún, en constatadores de circunstancias legales que les sirven para aplicar fórmulas matemáticas con el propósito de determinar un número de años de pena privativa de libertad. No obstante, una vez hallado el número de años, los jueces no analizan si éste resulta necesario, idóneo y proporcional, en atención a la historia de vida del condenado, para lograr su "resocialización".

Entonces, los jueces se han olvidado que la pena que imponen debe fundamentarse y determinarse de acuerdo a las carencias sociales, la formación, la cultura, las costumbres, etcétera, del autor del delito. El remedio del delito cometido en el pasado por el condenado se encuentra en la pena que debe a cumplir en el futuro. No es para otra cosa más que para esto, que sirve que el juez reconstruya el pasado durante el proceso penal. Por tanto, hay que recobrar el contacto que se ha perdido entre el pasado y el futuro dentro del proceso penal.

Si el juez impone una pena a quien ha cometido un delito, y esta tiene como fin la "resocialización", el juez necesita conocer a la persona a quien se la impone, pues como un ciego puede guiar a otro ciego sin que se caigan al abismo. El juez no tiene otra forma para resolver el problema del futuro, es decir, la "resocialización" del condenado más que mirando su pasado.

Por ello, es totalmente correcto lo señalado por el maestro italiano Carnelutti (2010):

\begin{abstract}
De cualquier manera que sea si hay un pasado que se reconstruye para hacer de él la base del futuro, en el proceso penal ese pasado es el del hombre en la jaula. No existe otra razón para establecer la certeza del delito, más que la de infligirle la pena. El delito está en el pasado, la pena está en el futuro. Dice el juez: debo saber lo que has sido para establecer lo que serás. Yo tengo en las manos la balanza; la justicia quiere que tanto como pesa tu delito, pese tu pena. (p. 29)
\end{abstract}

Otro problema que se advierte es que el juez, luego de emitir sentencia condenatoria, se olvida del penado. Al emitir su resolución se desliga de la ejecución de la misma, considera que su trabajo ha concluido, y que es asunto de la administración penitenciaria vigilar y controlar el cumplimiento de la pena. Pareciera que, para él, luego de que el procesado ha sido condenado, ha muerto; y que la lectura de su sentencia es el funeral, terminada dicha ceremonia al muerto no se le piensa más. Así, se puede comparar la cárcel con el cementerio, sin embargo, el condenado ha sido sepultado vivo.

Sin embargo, en lugar de asemejar la cárcel con un cementerio, deberíamos compararla con un hospedaje. Pues la condena no es más que la determinación del servicio de asistencia que requiere el nuevo huésped. El juez al emitir sentencia fija el servicio asistencial que debe recibir el condenado, por tanto, debe preocuparse de conocer lo suficiente a la persona que ha cometido un delito, $y$ ha sido etiquetado por él como delincuente, pues, solo así podrá determinar el servicio asistencial más adecuado para el condenado. 
Entonces, la cárcel es, verdaderamente, un hospedaje lleno de seres humanos que necesitan ser asistidos con hospitalidad, los cuales requieren sanar su espíritu, ser atendidos con inteligencia, paciencia y hasta con abnegación. Para ello, se debe saber con exactitud su historia de vida: carencias sociales, personalidad, costumbres, cultura, en resumen, lo que le falta aprender para vivir en sociedad. Y es que la delincuencia es producto de la pobreza, no sólo económica en algunos casos, sino sobre todo espiritual.

Es al espíritu del delincuente a donde debemos llegar, y ello se conseguirá sólo con una ética de la hospitalidad, una ética desde el otro y para el otro, como hemos señalado anteriormente, la falta de espíritu no se colma más que con el espíritu. La asistencia de la que el preso tiene necesidad es una asistencia espiritual. Sin embargo, la pena es un castigo. De acuerdo, pero el castigo no resulta incompatible con el amor. La palabra castigo proviene del verbo castigar y este del latín castigare. Este verbo está compuesto de castus que significa casto (ajustado a las reglas de convivencia social), y agere que significa hacer. $\mathrm{O}$ sea, hacer casto a una persona quiere decir instruirlo en las reglas de convivencia social.

Así las cosas, el problema no es de reformas legales penales sino de transformaciones personales. Las modificaciones legales no pueden hacer mucho por el condenado. La ley puede prohibir a los ciudadanos ciertas conductas bajo sanción de pena, pero no les puede infundir respeto y consideración por los demás. Entonces, es evidente que el problema del delito y de la pena deja de ser un problema jurídico para pasar a ser un problema socioeconómico y cultural.

Por tanto, todos debemos estar comprometidos en dicha tarea, pues, la criminalidad es un problema comunitario, su la solución está en la comunidad, y no en el sistema judicial punitivo. Todos somos colaboradores invisibles de la justicia. Por eso bien apunta Carnelutti (2010) al señalar que:

El condenado es el pobre, por excelencia, en su desnudez. No hay una necesidad más angustiosa que la necesidad del amor. Es necesario verlos, dentro del burdo uniforme a grandes rayas, hecho para separarlos de los otros hombres, alzar sobre nosotros una mirada, en la cual se expresa, aun cuando trate de ocultarse, el sentido mortífero de su inferioridad, para comprender el bien que puede proporcionar a ellos una sonrisa, una palabra, una caricia. Un bien del cual en un primer momento no se dan cuenta. Al cual incluso pueden, al principio, tratar de resistir, pero que después, poco a poco, se insinúa en ellos, se apodera de ellos, los conquista, los endulza, exprime de su corazón sentimientos que parecían sepultados y de sus labios palabras que parecían olvidadas. Es necesario haber vivido esta experiencia para comprender que nuestro comportamiento frente a los condenados es el índice más seguro de nuestra civilidad. (p. 31).

Al ver a los presos de nuestro país nos viene a la mente la figura del derecho romano denominada homo sacer, la cual ha sido muy bien estudiada y explicada por el filósofo italiano Giorgio Agamben. El homo sacer no podía ser sacrificado por el Imperio Romano, sin embargo, podía ser asesinado por cualquier ciudadano impunemente, pues, su vida no tenía valor alguno para la comunidad. Es decir, ya no era una persona para el Estado, no importaban sus derechos fundamentales, estaba echado a su suerte, era un enemigo de la comunidad, por eso estaba desprotegido.

Sin embargo, en nuestro país lo dicho no sólo ocurre cuando el preso se encuentra en la cárcel sino también cuando egresa físicamente de ella, es decir, es discriminado también cuando sale de prisión por la sociedad. Para la sociedad el preso siempre es el preso, es más, le dicen ex recluso, y piensan que como ha robado podría volver a robar, entonces, no le dan trabajo. Así "razona" la gente. Entonces, qué sentido tiene afirmar que quien ha cumplido la pena se ha rehabilitado, si las personas creen que cada uno seguirá siendo lo que es, cuando lo cierto es, como enseñaba Heráclito, que "todo cambia".

Entonces, es importante que la ciudadanía comprenda que resulta sumamente importante que sea hospitalaria con quien egresa de la cárcel. El liberado se siente como un extranjero al retornar a la sociedad después de haber estado por mucho tiempo privado de su libertad, podríamos asemejar dicha experiencia con la de un inmigrante que deja su comunidad para ir a otra. Estar en sociedad, sin duda, ahora le resulta más difícil que antes, pues, han recobrado su libertad, pero junto a ella existe un miedo que la acompaña. El liberado sabe que, tras haber estado en prisión, será aún más complejo reinsertarse a la sociedad, ya que 
carga un estigma carcelario que lo acompañará por el resto de su vida.

Por ello, debemos aseverar que la ética de la hospitalidad no sólo concierne a los operadores del sistema punitivo sino a la comunidad por completo, sino estamos dispuestos a abrirnos para asistir y aprender del otro no tiene sentido expresar constitucionalmente que, quien ha cumplido su castigo puede reinsertarse a la sociedad. Sólo transformando a la sociedad el estigma del liberado de la cárcel será borrado para siempre. Se vuele necesario desarrollar nuevas sensibilidades en nuestra percepción acerca de la pena, provocar que el castigo ya no sea visto como un fetiche normalizado.

Sin embargo, observamos que recientemente se han expedido normas penales que inhabilitan a personas condenadas por algunos delitos a obtener ciertos empleos o realizar determinadas actividades, inclusive de por vida. Entonces, quien es liberado se choca con la realidad y, día tras día, experimenta su exclusión social, llegando a pensar que mejor estaba en la cárcel. Con ello, constatamos que la realidad nos demuestra que la pena no dura unos años sino es de por vida. Surgiendo la pena perpetua del rehabilitado o liberado.

Quizás ahora se observe, con mayor claridad, porque líneas atrás afirmamos que el Derecho Penal se ha estructurado en base al dolor y sufrimiento de las personas, y que, sino deconstruimos su discurso punitivo de manera radical no habrá humanidad dentro de él. Pues, hasta ahora sólo ha quedado demostrado que su tesis, la cual consiste en afirmar que los "delincuentes" son quienes perturban la tranquilidad social, y que, encerrándolos en la cárcel se eliminará dicha perturbación, ha resultado inválida.

Sin embargo, lo que dicha tesis sí ha conseguido es discriminar de por vida a quienes han cometido un delito. Cuando la realidad demuestra que las prisiones no son lugares diferentes al resto del mundo, Ya que la cárcel es un mundo, y el mundo, hoy más que nunca, ha demostrado ser una prisión para las personas, sobre todo, cuando vemos tantos humanos presos de sus dependencias emocionales, adicciones laborales, consumismo, etcétera. Por tanto, afirmar que dentro de las cárceles solamente existen malos, y fuera de ellas buenos, es sólo una ilusión, como también lo es que un ser humano sea sólo bueno o sólo malo.
No obstante, con esto no estamos negando la necesidad de la pena, pero no hay que perder de vista que toda necesidad es una insuficiencia. Lo que queremos transmitir no es que el Derecho Penal sea innecesario, sino que el Derecho Penal sea inidóneo para reducir la criminalidad existente. Pues, esta es la idea que, lamentablemente, comunica el discurso punitivo contemporáneo a través de sus escritores y oradores, es decir, de las agencias del sistema punitivo.

Ello ha generado un fetichismo punitivo, ya que denominar a esta manifestación populismo o simbolismo punitivo, en nuestros tiempos, resulta insuficiente. Cuando hace algunos años, Winfried Hassemer o Alessandro Baratta denunciaban que el Derecho Penal era meramente simbólico, señalando que las funciones manifiestas de la pena no eran las latentes o reales, agregaban que esta estrategia era un engaño de quienes ejercían el poder punitivo. Sin embargo, hoy podemos afirmar que ya nadie nos engaña, todos sabemos que el Derecho Penal no está sirviendo para nada, y que sus funciones manifiestas no se cumplen en absoluto.

Entonces, ya no somos engañados, sino somos conscientes de que la pena no sirve para lo que se dice que sirve, es decir, que es un objeto que no cumple con su objeto. Por ende, es un ente que no cumple con su función manifiesta, sin embargo, nosotros, pese a ser consciente de ello, le seguimos atribuyendo dichos "poderes mágicos", vale decir, en nuestra mente le otorgamos a dicho objeto algo para lo que no es propio, pues, ha quedado demostrado que no es apto para cumplirlo.

Así, constituimos a la pena como un fetiche, le asignamos una propiedad que no posee. Ahora bien, lo hacemos porque eso nos da placer, porque tenemos una gran adicción por ella, una gran inversión emocional en ella. El fetiche es un apego, un desorden emocional que le resulta funcional al fetichista porque substituye una carencia, o sea, llena un vacío existente en él. ¿Qué vacío llena la pena?

Sin lugar a dudas, la pena llena la inseguridad que sentimos tras observar, en los medios de comunicación social, que existe un gran índice de criminalidad en nuestro país. Nos sentimos más tranquilos al saber que existe una pena grave o muy grave si se comete un delito 
que vemos con frecuencia en la televisión o los periódicos. Entonces, el fetiche se vuelve una fantasía, una realidad alternativa que está conformada por teorías legales, de las cuales se piensa, que, por estar establecidas en una norma penal, se van a cumplir. A lo que muchos penalistas emocionados le denominan dogmática penal.

Ante ello, surge la imperiosa necesidad de salir de este laberinto de conceptos jurídicos que no brindan una solución real al problema de la criminalidad, sino construyen placebos legales sin voluntad política práctica. En suma, lo que esta versión de Derecho Penal podría logar, como máximo, es que los ciudadanos respeten las normas jurídicas, y si no lo hacen, sean sancionados y aislados en la cárcel. Sin embargo, este respeto, y el eventual castigo, no hará desaparecer la división y diferenciación entre los ciudadanos, y eso, para nosotros resulta ser lo más importante de superar.

Si aún somos castigados es porque no hemos sido capaces de encontrar otro sistema legal que impidan ver a la pena como la solución a nuestros conflictos y/o diferencias, es nuestra falta de imaginación la que nos hace merecedores de dicho castigo como sociedad.

\section{DE LA "IMAGINACIÓN" PENAL A LA IMAGINACIÓN CRIMINOLÓGICA}

Etimológicamente la palabra imaginación proviene del sustantivo latino imaginatio, el cual está compuesto por la unión de la palabra imagina, que significa idea, y el sufijo tio, que significa acción de, resultado o proceso, por tanto, este término expresa la acción o resultado de representarse una idea o pensamiento.

Según el diccionario de la Real Academia Española la palabra imaginación tiene cuatro acepciones:

1.f. Facultad del alma que representa las imágenes de las cosas reales o ideales.

2.f. Aprensión falsa o juicio de algo que no hay en realidad o no tiene fundamento.

\section{3. f. Imagen formada por la fantasía.}

4. f. Facilidad para formar nuevas ideas, nuevos proyectos, etc.
De las acepciones antes citadas podemos observar dos significados contrapuestos de dicha palabra, por un lado, un sentido positivo que la identifica con la capacidad de formular ideas nuevas, y por otro, un concepto negativo que la asemeja a un prejuicio ilusorio que no tiene soporte real. Ello, nos revela la complejidad de este término tan importante en la actividad mental humana.

Consideramos que la imaginación tiene un rol esencial en la percepción que tenemos de la realidad y en la formulación de nuestros pensamientos, que la inteligencia y la creatividad dependen de ella, y que fomentándola podremos progresar hacia una sociedad crítica e igualitaria.

La filosofía desde sus orígenes consideró que la imaginación tiene un rol trascendental en la creación del conocimiento humano. De igual forma, la ciencia contemporánea está descubriendo que es una función cognitiva fundamental de nuestra mente, pues, gracias a ella podemos pensar más allá de nuestra situación inmediata, generando contenidos para revaluar el pasado o construir un posible futuro.

Nuestras ideas nacen como imágenes. Es más, etimológicamente la palabra idea proviene de visión, por tanto, idear es imaginar. Sin imaginación no habría lenguaje, pues, gracias a ella las palabras evocan ideas o entes ausentes. Entonces, la imaginación es vida, nos permite pensar, crear, comunicar, interactuar con los demás, conectar con los otros, sin ella sería imposible ser empático, ya que la empatía es la capacidad de imaginar lo que otra persona siente.

Cuando siento empatía, una parte de mí deja de estar en mí y, a través de la imaginación, viaja hacia el otro. En cambio, el egoísta es incapaz de imaginar en el otro la interioridad que lo convierte en persona. Sólo ve lo que concierne a sus designios, y como utilizar al otro. Entonces, una educación que descuida la imaginación es una educación sin humanidad y propósito.

El ser humano es un ser eminentemente imaginativo, y aunque no todo acto imaginativo es creador, la creatividad requiere de la imaginación. La imaginación creadora precisa de conocimientos y percepciones que la estimulen sin abrumarla, y de una motivación 
que la guíe sin controlarla rigurosamente. Sin embargo, en la actualidad vivimos en un mundo carente de imaginación, y saturados de datos, cifras y códigos de barras. La televisión, las redes sociales, la prensa escrita, etcétera, han atrofiado nuestra capacidad de imaginar.

Todo ello nos revela que, para transformar nuestra sociedad, necesitamos desarrollar nuestra imaginación, pues, la gran mayoría de instituciones y estructuras caducas que nos rodean están en decadencia precisamente por falta de imaginación. El poder de la imaginación es hoy esencial para renovar la educación, la política y la vida cotidiana.

La congénita irracionalidad del Derecho Penal necesita de un discurso punitivo "muy imaginativo" que la justifique. Este discurso es de vital importancia en la estrategia de dominación social de los grupos que aspiran a ejercer poder, pues, quienes controlan los discursos más influyentes, como lo es el punitivo, tienen mayores posibilidades de controlar la mente de las personas. Asimismo, la mejor manera de ejercer el poder es de forma sutil y rutinaria, ya que su eficacia se concreta cuando quienes lo ejercen consiguen que quienes no lo tienen vean e interpreten el mundo desde su perspectiva sin darse cuenta.

Al resultado de obtener lo antes señalado utilizando la persuasión emocional se le denomina hegemonía. Este proceso parte de establecer que toda interacción comunicativa cotidiana tiene una dimensión política, pues, todo texto tiene la potencialidad de estructurar relaciones de poder y subordinación. Sin lugar a dudas, este mecanismo se presenta en el discurso punitivo con gran intensidad, ya que el sistema penal constituye una de las expresiones más agudas de discriminación social.

Por tanto, para comprender al poder punitivo no basta con acudir a la realidad fáctica, o a los principios del Derecho Penal, sino que debemos tener presente al discurso punitivo. Caso contrario, no vamos a poder entender su estrategia del miedo al delito y la pena que propone. Por ello, es importante diferenciar dentro de él al discurso que se encarga de legitimar la criminalización de conductas de aquel que se opone a la criminalización.

Teniendo en cuenta el contexto social, el discurso de la seguridad ciudadana se encarga de legitimar las conductas que el control social formal debe proteger penalmente, y el discurso de exclusión de criminalización, al servicio de las clases más poderosas, de eliminar ciertos conflictos sociales del poder punitivo. Ello nos revela que los sistemas penales criminalizan y castigan las conductas dependiendo de las características socioeconómicas de los ciudadanos, y que la esencia de dicho discurso es su naturaleza discriminatoria.

De esta manera, el discurso punitivo afecta transversalmente a la política criminal, pues, no solo define qué conflictos deben protegerse penalmente y legitima los fines de la pena, sino que también incide en todas las instituciones y fases de criminalización, es decir, en los debates parlamentarios, la actuación de la policía, la aplicación del derecho penal por parte de los operadores del sistema judicial, la elaboración de la dogmática penal y la ejecución de la pena.

Asimismo, este Derecho Penal neoliberal discriminatorio resulta totalitario, pues, ha asumido todas las formas de control social disponibles, convirtiéndose en el código moral de nuestros días, lo cual ha generado la juridización de todos los ámbitos sociales. Además, se ha centrado en la discusión sobre la criminalización o no de conductas, en este debate hemos caído todos, pese a saber que el Derecho Penal no resuelve conflictos sociales. Igualmente, se utilizan las tasas de criminalidad existente para sustentar la penalización de conductas, cuando sabemos que el aumento o disminución de los niveles de criminalidad no guardan relación directa con una mayor intervención penal, ya que el crimen es pluricausal y multifactorial.

Sin embargo, la característica esencial del discurso punitivo es su especial capacidad para ser ajeno a la realidad, ya que la realidad no se ve reflejada en él, sino que el discurso tiene vida propia, por tanto, éste no interpreta hechos existentes sino crea realidades inexistentes, es decir, es imaginativo en sentido negativo, pues, es el resultado de una valoración falsa o juicio de algo que no hay en realidad, que no tiene fundamento.

De esta manera, el discurso punitivo simplifica la explicación y compresión de un determinado conflicto social. Un medio que lo facilita son las denominadas representaciones sociales. La construcción de estas percepciones 
compartidas se origina de la hipótesis de que los ciudadanos resultan incapaces de comprender todos los detalles de un determinado problema social y, más aún, si es de la complejidad de la criminalidad y de los medios de control social. Para ello organizan mentalmente estos significados mediante representaciones sociales.

Existen diversas estructuras semánticas que sirven para crear representaciones sociales, como las metáforas, eufemismos, redundancias, etcétera. Una de éstas son las fracturas de imagen, funcionan creando vínculos entre determinadas afirmaciones y las áreas de experiencia de los receptores del discurso, superando las posibles contradicciones y generando, a la vez, creencias y aceptaciones compartidas. Por ejemplo, cuando un medio de comunicación afirma que una oleada de delincuencia pone en peligro el comercio de la ciudad, constituye una fractura de imagen, porque los símbolos comercio (que significa progreso) y oleadas (que señalan una amenaza proveniente del exterior) vinculan dos imágenes que sirven para crear una representación social o simbolismo colectivo, que posteriormente contribuirá a una determinada actitud frente a la delincuencia.

Por otro lado, las representaciones sociales también tienen una parte neurológica, la cual está conformada por los instintos, sentimientos y pensamientos. Los seres humanos tenernos tres cerebros:

1. El reptiliano (instintos) situado en el tallo encefálico, regula nuestras funciones vitales para la supervivencia. Da respuestas automáticas y programadas. Es resistente a los cambios y a la improvisación. Se centra sobre todo en el presente.

2. El límbico (sentimiento), controla las respuestas emocionales. Entre las que destacan el miedo a lo desconocido, el apego, el amor, la envidia, etcétera. Con este cerebro surge la manada y las relaciones sociales. Gracias a él surge el aprendizaje asociativo, ya que guarda los recuerdos emocionales que más impactaron en nuestras vidas. Se centra sobre todo en el pasado, de acuerdo a como desarrollemos nuestros apegos gestionaremos nuestras emociones. Permite experimentar nuestras vidas a través de las imágenes y emociones desarrolladas en nuestro entorno social.
3. El neo córtex (pensamiento y razonamiento). Permite tener conciencia y desarrollar capacidades cognitivas como la concentración, el lenguaje simbólico, la invención, la habilidad de escoger, el pensamiento abstracto, la imaginación, etcétera. Gracias a él surge la capacidad de descubrir nuevos horizontes, aparece el altruismo, la compresión de las relaciones sociales existentes, se puede anticipar reacciones, resolver de conflictos y la planificar a largo plazo. Se centra sobre todo en el futuro, pues nos permite imaginar, proyectar, gestionar nuestras emociones dependiendo del contexto y las reacciones futuras de nuestro entorno, saber que nuestro tiempo es limitado, etcétera.

Nuestro cerebro demuestra que ponemos en marcha el instintito y la emoción antes que la razón. Lo cual, revela porque la criminalidad y su respuesta social se afrontan más con las reacciones instintivas y las emociones que con el razonamiento. Así, la sociedad se ha visto obligada a imponer normas externas destinadas a contener la desbordante marea de los excesos emocionales que brotan del interior del individuo.

Debido a nuestro cerebro reptiliano y límbico, nuestros mecanismos de estímulo y respuesta, los cuales también son utilizados en la comunicación, buscan fundamentalmente lo conocido y la reducción del miedo. La disminución del miedo es la que genera una respuesta innata de nuestra especie: la búsqueda de seguridad. Así, la previsibilidad elimina la incertidumbre. Por ende, lo que no es familiar es hostil por desconocido; por esta razón, toda política criminológica alternativa es rechazada.

El discurso político criminal se ve atrapado, de esta manera, por la tendencia humana de permanecer en lo conocido. El Derecho Penal contemporáneo, fundamentado en la pena, supone una respuesta previsible al miedo que, además, se entiende con un mínimo gasto de energía cognitiva. El principio de economía cognitiva señala que solemos elegir la solución que menor costo de energía exija, por tanto, buscamos siempre estar en el mundo de lo previsible y rutinario.

Así, la sustitución de la realidad por un discurso punitivo, apoyando por los 
medios de comunicación social, genera que nuestras relaciones sociales "funcionen" previsiblemente. Lo que los medios no transmiten, sencillamente, no existe, porque la mayor parte del conocimiento sobre la realidad que poseen las personas proviene de la selección temática realizada por dichos medios que, a la vez, tienden también a aplicar el principio de economía cognitiva, y son dirigidos por quienes ejercen el poder punitivo. De esta manera, la creación de representaciones sociales, estereotipos y prejuicios son manifestaciones del principio de economía cognitiva que en las mayorías de las ocasiones buscan eliminar la incertidumbre y el miedo.

En resumen, el discurso punitivo se ha generado desde el cerebro reptiliano y límbico, es decir, persigue la reducción del miedo y la obtención de seguridad. Así, la búsqueda de lo previsible y el principio de economía cognitiva son mecanismos (mentales) utilizados por los creadores del discurso punitivo para que los receptores del mismo demanden la imposición del castigo para reducir el miedo al delito que tienen.

Por otro lado, consideramos que cualquier conflicto social puede ser analizado criminológicamente. Aprender a pensar criminológicamente requiere cultivar la imaginación. La criminología no puede aprenderse de forma rutinaria, pues, implica liberarse lo más posible de circunstancias personales (como los prejuicios o traumas vividos) para poder entender la vida social desde un contexto mucho más amplio. El trabajo que esto implica debe ser denominado imaginación criminológica, esto nos permite pensar distanciándonos de las acciones mecánicas, y ver los hechos como algo nuevo y fascinante que merecen toda nuestra atención, para ser analizados desde distintos enfoques, pues, todo acto social:

1. Es parte de una actividad humana, en el que importa más el símbolo que la sustancia, y es el centro de muchas interacciones personales que se comparten con otras personas como un rito social.

2. Forma parte de una compleja serie de relaciones sociales y económicas que se extienden por todo el mundo.
3. Supone un proceso de desarrollo político, social y económico.

4. Es producto del mundo contemporáneo, y se encuentra situado en los debates que en la actualidad se ocupan de la globalización, los derechos humanos, el medio ambiente, etcétera. Es decir, se encuentra politizado y etiquetado.

Lo que debe buscar la imaginación criminológica es hacernos conscientes de las diferencias culturales, lo que nos permitirá contemplar el mundo desde diversos paradigmas, ya que si entendemos adecuadamente cómo son, piensan, actúan y viven los otros tendremos una mejor comprensión de cuáles son sus problemas. Las políticas criminológicas que no se encuentran cimentadas en un aprendizaje de quienes afectan no tienen posibilidades de éxito. Debe situar la biografía humana en la historia y la estructura social. Actuar de puente entre la vida interna de los actores y el marco histórico y social en el que se encuentran. Unir la historia de vida de las personas con las estructuras de poder, la ideología y el momento histórico que viven, es decir, hacer político lo personal.

La Criminología debe generar un movimiento desde el medio local al sistema total, y a la inversa, por tanto, debe abandonar el empirismo abstracto, que se centra únicamente en lo local de forma distante y extraña, y a la Gran Teoría, a la que sólo le importa el sistema y se abstrae de la historia y la estructura social, distanciándose de la realidad social. La Gran Teoría se convierte en un idealismo neo kantiano, en el que la categorización de sus múltiples conceptos se vuelve el objetivo primordial. Por su parte el empirismo abstracto ha burocratizado la investigación criminológica, se ha vuelto un ritual metodológico y estadístico que desprecia a la filosofía social, y en donde se escriben libros sacados de otros libros. Así, la Criminología se parece al Derecho Penal que tanto criticaba, pues se vuelve especulativa, o puramente formal.

Debemos democratizar la Criminología, no debe ser cuestión de una elite de intelectuales. Esto nos permitirá pasar de los problemas personales en un entorno a los problemas públicos de la estructura social. Pues, al observar los problemas personales nos daremos cuenta 
que son problemas colectivos. Esta relación de lo personal con lo colectivo permitirá revelar el significado humano de los asuntos públicos. Entonces, debemos desarrollar una imaginación criminológica para que los objetos de estudio de la Criminología sean vistos de manera novedosa y diferente, pero sobre todo para provocar la transformación del comportamiento de los individuos hacia la deferencia y la hospitalidad.

La Criminología debe denunciar que vivimos en un mundo vertiginoso caracterizado por la inestabilidad en el trabajo, la familia y la comunidad, lo cual produce incertidumbre económica, escases de oportunidades, y medidas de justicia arbitrarias y torcidas. Demostrar que actualmente existen barreras diferenciadoras a base de relegar al estado de otredad a todo lo que nos incomode. En consecuencia, se hace imperiosa la necesidad de una respuesta alternativa que deconstruya dichas culturas para darle la bienvenida a la creatividad humana y celebrar la diferencia. Una Criminología que con su imaginación convierta la indiferencia en deferencia, y la hostilidad en hospitalidad.

\section{CONCLUSIONES}

Lo que necesitamos en rigor es un discurso punitivo desde y para el otro, cambiar el orden, deconstruir, hacer que lo importante sea lo escrito y no lo que se dice o habla, es decir, hacer real lo escrito. Esto se conseguirá en la medida que logramos eliminar el fono centrismo del discurso punitivo contemporáneo, el cual pretende hacer creer a todos que el habla se encuentra primero que la escritura, pues, es previo a ella.

Para dicho propósito resulta clave demostrar que la escritura es previa al habla, hacer notar que quien habla está escribiendo en su mente utilizando la gramática punitiva previamente configurada, y por ello, debe respetar el orden establecido por ella, sus funciones y sentidos, es decir, los fines de la pena. Debe señalar enfáticamente que nada hay fuera del texto, y con dicha frase debe enfrentarse a los poderes que intentan esconderse por fuera del texto para torcerlo y perjudicar el bienestar social.

En suma, lo que se busca es dar muerte a ese discurso punitivo dogmático, encerrado en la caverna de la teoría pura del Derecho, para abrir paso a una nueva criminología, construida desde la imaginación criminológica. El cual busca constituirse como un dialecto nacional coherente al lugar donde se va a hablar, con la finalidad de generar una multiplicidad y diversidad lingüística que incluya a todos. Solo así, esta Criminología diferente, y sobre todo deferente, será legítima, pues la verdad no es única, es decir, no hay hechos sólo interpretaciones. Esta nueva Criminología dará lugar al respeto por las minorías, por los diferentes, por los otros.

De esta manera, se producirá una estética de la diferencia, que el sistema neoliberal controlado por los grandes poderes económicos se niega a permitir, pues pondría en riesgo su afán por constituir seres humanos egoístas que compitan por tener más riqueza, con el único propósito de consumir lo que el mercado les ofrece para la satisfacción de sus placeres. Lo que venimos a proponer con este trabajo de investigación es un pensamiento criminológico crítico y realista desde y para el otro, una forma de hacer criminología diferente, de hacerla aprendiendo del otro, de quien ha cometido un delito, pues solo comprendiéndolo y asistiéndolo podremos transformar nuestra comunidad, tan sólo demostrando empatía y solidaridad con los más vulnerables podremos cambiar nuestro orden y estructura socioeconómica.

Finalmente, debemos decir que en el anonimato nadie puede recibir hospitalidad. Por tanto, debemos hacer visibles los rostros de quienes se encuentran privados de libertad, solo así el huésped estará protegido por la ley y el Derecho. La hospitalidad exige dejar de desviar nuestra mirada para observar el rostro del otro, sólo así podremos conocer sus carencias y reconocerlo como nuestro hermano, debemos utilizar nuestro neo córtex para ser empáticos, altruistas y deferentes, así, en el poco tiempo de vida que tenemos en el mundo, habremos servido y asistido a quien más nos necesita.

\section{FUENTES DE INFORMACIÓN.}

Carnelutti, F. (2010). Las miserias del proceso penal. Bogotá, Colombia: Editorial Themis

Derrida, J. (1971). De la gramatología. Buenos Aires, Argentina, Editorial Siglo XXI. 

criminológico deferente y hospitalario

Deconstructing the contemporary punitive speech: introduction to a deferent criminological and hospital thought

Foucault, M. (1976). Vigilar y castigar. Buenos Aires, Argentina: Editorial Siglo XXI.

Heidegger, M. (2003). Ser y tiempo. Madrid, España: Editorial Trota.
Huamán, M. (2006). Claves de la deconstrucción. Lima, Perú: Universidad Nacional Mayor de San Marcos. 